\title{
ANALYSIS OF SIMPLE FINANCIAL BOOKKEEPERS FOR THE VEGETABLE VENDORS IN EAST BOGOR REGION
}

\author{
Retno Martanti Endah Lestari ${ }^{\text {a)}}$, Siti Maimunah ${ }^{\text {a) }}$ \\ ${ }^{a)}$ Universitas Pakuan, Bogor, Indonesia \\ Corresponding Author: retno.martanti@unpak.ac.id
}

Article history: received 30 December 2018; revised 25 January 2019; accepted 01 February 2019

\begin{abstract}
Recently there are many vegetable vendors who have difficulties in managing their financial bookkeepers. In maintaining their capital, they borrow some money from moneylenders or mobile banks that provide higher interest than the state bank. The aim of this study is to analyze how they can maintain their financial skill. This type of research is a descriptive development survey with a qualitative research technique. Data are collected from primary and secondary data by using the questionnaires. The stratified sampling method used by taking grouping respondents get 34 people from 92 populations spread across the Bogor region. The result of this study describes there are still many vegetable vendors do not have capabilities in simple bookkeeping skills in the East Bogor Region. A lot of them do not separate the financial management of their business with their personal life. They don't take notes on the entry and expenditure because they think it's too complicated and time-consuming. Even though they have difficulties in detecting pure profits from the sales, they still borrow some money from moneylenders to generate their capitals. They do not understand what the impact of it.
\end{abstract}

Keywords: vegetable vendors, simple financial book-keeping

\section{INTRODUCTION}

Bogor is a city in West Java Province, Indonesia. It is located $59 \mathrm{~km}$ south of Jakarta, and the area is in the middle of the Bogor Regency area. Formerly the area was $21.56 \mathrm{~km}^{2}$ but has been growing to $118.50 \mathrm{~km}^{2}$ and the population now is $1,030,720$ people (2014). Bogor is trade, and services, as well as city service facilities. The western part of West Bogor sub-district has the potential as a residential area supported by tourism objects. The eastern part of the East Bogor District has the potential as a residential area. The central part of the Central Bogor District has the potential to be a center of trade and services supported by offices and scientific tourism [1].

The East Bogor District consists of 6 urban villages including the Baranangsiang Village. The population of Baranangsiang Village is 23,770 people, where the number of male population is 11,780 people, women are 11,990 people, the number of heads of households (KK) is 6,458 households. [1]

Baranangsiang is one of the villages in the East Bogor District, West Java, Indonesia. It is one of the vital villages in Bogor because there is the main bus terminal in Bogor, the Baranangsiang Bus Terminal.

Baranangsiang Village has the potential to be a non-pollutant industry area, therefore the livelihoods of the people are spread into various professions such as employees of private companies, small and medium entrepreneurs, etc. as shown in table 1.

Based on the data in table 1 , information can be obtained that the local traders only $0.1 \%$ of the total types of work in the Baranangsiang sub-district,
Table 1. Types of Community Work Baranangsiang Village In 2016

\begin{tabular}{|l|l|l|l|l|l|}
\hline No & Types Of Works & Male & Female & Total & $\%$ \\
\hline 1. & Private Employees & 8.281 & 6.039 & 15.320 & 85,3 \\
\hline 2. & Civil Government & 780 & 424 & 1204 & 6,7 \\
\hline 3. & State Employees & 350 & 235 & 585 & 3,3 \\
\hline 4. & Pension & 250 & 220 & 470 & 2,6 \\
\hline 5. & $\begin{array}{l}\text { Small, medium and } \\
\text { large entrepreneurs }\end{array}$ & 45 & 25 & 70 & 0,4 \\
\hline 6. & $\begin{array}{l}\text { Indonesian National } \\
\text { Army }\end{array}$ & 44 & 2 & 46 & 0,3 \\
\hline 7. & Maid & 35 & 78 & 113 & 0,6 \\
\hline 8. & $\begin{array}{l}\text { Indonesian republic } \\
\text { police }\end{array}$ & 25 & 5 & 30 & 0,2 \\
\hline 9. & Private Lecturer & 15 & 5 & 20 & 0,1 \\
\hline 10. & Salesman & 12 & 5 & 17 & 0,1 \\
\hline 11. & Mechanic & 10 & - & 10 & 0,1 \\
\hline 12. & Architecture/Designer & 10 & - & 10 & 0,1 \\
\hline 13. & Craftmen & 8 & 2 & 10 & 0,1 \\
\hline 14. & Farmer & 5 & - & 5 & 0,0 \\
\hline 15. & Lawyer & 5 & 2 & 7 & 0,0 \\
\hline 16. & Migrant Worker & 4 & 5 & 9 & 0,1 \\
\hline 17. & Private Physician & 4 & 2 & 6 & 0,0 \\
\hline 18. & Private Nurse & 4 & 5 & 9 & 0,1 \\
\hline 19. & $\begin{array}{l}\text { Alternative Medicine } \\
\text { Expert }\end{array}$ & 3 & 2 & 5 & 0,0 \\
\hline 20. & Artist & 3 & 2 & 5 & 0,0 \\
\hline 21. & Notary & 2 & 2 & 4 & 0,0 \\
\hline 22. & Labor Farmer & - & - & - & - \\
\hline 23. & Breeder & - & - & - & - \\
\hline 24. & Private Midwife & - & 4 & 4 & 0,0 \\
\hline 25. & Traditional Shaman & - & 5 & 5 & 0,0 \\
\hline & Total & 10.895 & 7.069 & 17.964 & 100,0 \\
\hline & & & & \\
\hline aurce & & & & \\
\hline
\end{tabular}

(source: http://kotabogor.go.id)

But the reality in the community, more than $1 \%$ of the population has a profession as traders around, especially vegetable traders. If it is seen from the number of residents who work as Private Company 
Employees as much as $85.3 \%$, of which $39 \%$ are female, this is the potential and opportunity needed by mobile vegetable traders considering there is not enough time for these women to go to the market to buy their daily needs. Mobile traders can be categorized as Small Traders.

Small traders are substantially interpreted as small business communities engaged in trade with a relatively small, limited and non-permanent business environment.

In this sense, street vendors are often characterized by slow money circulation, irregular business places, limited capital, market segments in the middle to lower class of society and business opportunities that are not too broad (Zuhriski [2]).

Researchers saw many vegetable vendors having difficulties managing their finances. This can be seen with many of them who often borrow money for capital from moneylenders or mobile banks that provide interest conditions that are far higher than bank interest. Under these circumstances, the Researcher felt called upon to assist the middle and lower economic community to take part in providing financial management training in their business. However, the researcher wanted to conduct a survey in advance about simple bookkeeping skills for the traveling Vegetable Traders in the East Bogor area.

For this reason, the researcher was interested in taking the title of Simple Bookkeeping Capability Analysis for Roving Vegetable Traders in the East Bogor Region, so that the researchers formulated the problem that the extent of the simple bookkeeping ability for mobile vegetable traders in the East Bogor Region?

The objectives to be achieved in this study are to analyze the extent to which simple bookkeeping skills for mobile vegetable traders in the East Bogor Region.

\section{Understanding of Ability}

According to the Republic of Indonesia Law No. 9 of 1995 concerning small businesses, small businesses are small-scale people's economic activities and meet the criteria for annual wealth or sales proceeds:

(1) have a net worth of at most Rp. 200,000,000 excluding land and construction of business premises,

(2) have annual sales of a maximum of Rp1,000,000,000

(3) belonging to Indonesian citizens,

(4) stand-alone, and

(5) individual business forms.

The capability is the capacity of an individual to carry out various tasks in a job. Ability is also a current assessment of what a person can do. [3]

Intellectual ability is the ability needed to perform various mental activities - thinking, reasoning, and solving problems. Individuals in most societies place intelligence, and for the right reasons, at high values. Smart individuals are also more likely to be leaders in a group. [3]

Intellectual ability according to Goleman [4] is the ability to recognize our own feelings and other people's feelings, the ability to motivate ourselves and the ability to manage emotions well in themselves and in relationships with others, while Robbins [5] states ability is the capacity needed to carry out mental activities.

Physical ability is the ability of task that requires stamina, skill, strength, and similar characteristics. Research on the various requirements needed in hundreds of jobs has identified nine basic capabilities included in the performance of physical tasks. Every individual has different basic abilities.

Certain intellectual or physical abilities needed to do work adequately depend on the requirements of the ability and the job. For example, aircraft pilots need strong spatial visualization capabilities; coastguard officers need strong spatial visualization skills and good body coordination; senior executives need verbal skills, and high construction workers need balance. Examples of capabilities based on wikipedia.com [3]:

1. Academic skills

- Reading

- Logic

- Critical reasons

2. Interpersonal communication

- Speech: listen, speak

- Nonverbal communication

- Literacy: writing, reading

3. Motor skills

- Walking, art, crafts, sports

4. Trained workers

5. Innovation expertise.

\section{Simple Bookkeeping}

Accounting is the act of recording financial transactions. They include sales, purchases, income, and expenses by individuals or organizations. Bookkeeping is usually done by a bookkeeper. Bookkeeping is different from accounting. The accounting process is usually carried out by an accountant. He makes reports of recorded financial transactions written by bookkeepers.

There are several general methods of bookkeeping, such as single-entry and bookkeeping systems in pairs, these two systems can be seen as "real" accounting. Every process involved recording financial transactions is a bookkeeping process.

A bookkeeper, also known as an accounting registrar or Mechanical technician, is someone who records the daily transactions of an organization. A bookkeeper is usually responsible for writing "diaries". The diary contains purchases, sales, receipts, and expenses. Bookkeepers are responsible for ensuring all 
transactions are truly recorded in diaries, supplier ledgers, consumer ledgers, and general ledgers. Bookkeeping experts move the books to the balance sheet level. A bookkeeper prepares an income account and balance sheet using the trial balance and ledgers prepared by the bookkeeper.

The two bookkeeping systems commonly used in the business world and other organizations are single-entry and bookkeeping systems in pairs. Singleentry bookkeeping systems only use income and expenditure accounts, recorded mainly in the income and expenditure journals. Single-entry bookkeeping is suitable for micro and small businesses. Bookkeeping in pairs requires posting each transaction twice, using debit and credit.

The source of the primary bookkeeping record in single-entry bookkeeping is a cash book, similar to a list of current accounts, but puts income and expenses into various income and expenditure accounts. Separate account records are maintained for small cash, the status of the accountability and acceptability of the account, and other corresponding transactions, such as inventory and travel costs.

Simple bookkeeping for individuals and families involves recording the latest income, expenses, and balance sheets in the cash notebook or check account list. A diary for bookkeeping context is a financial transaction record with two characteristics, namely descriptive (orderly) and chronological (orderly). The diary is sometimes also called the book of original entry.

Details of the diary must be entered officially into the journal to facilitate the process of sending (posting) to the ledger. Diary includes:

1. A sales diary, to record all sales invoices.

2. Sales credit diary, to record all sales credit notes.

3. A purchase diary, to record all purchase invoices.

4. Purchase credit diary, to record all purchase credit notes.

5. A cash diary, commonly known as a cash book, to record all funds received or issued. The cash diary divides into two types, namely the receipt diary for the money received, and the expenditure diary for the money spent.

Simple Bookkeeping Objectives

1. The simple bookkeeping goals are:

Protecting business money

2. Analyzing the Source of Business Income

3. Monitor where money flows

4. Knowing the current business financial position

5. Better business decision making, because based on accurate data, a well-planned business pattern can be planned

6. Increasing Business Performance, so that with the existence of financial statements, the value of your business will increase in the eyes of investors

7. Knowing the data of any supplier whose debt is due
8. Know which consumer data is delayed to pay the receivables

9. Plan cash-flow, whether or not you need to take additional capital from investors.

\section{Benefits of Simple Bookkeeping}

According to Darsono and Ashari [6], the preparation of financial statements must refer to generally accepted accounting principles (PABU), which is a good habit or rule for preparing financial statements. Bookkeeping system becomes a vital means of entrepreneurship. With the bookkeeping system, entrepreneurs can calculate, control and regulate the overall financial transactions that occur throughout the sustainability of their business.

Entrepreneurs, both beginner, and professionals have a good understanding of preparing a bookkeeping system, at least the simplest. Although it can be done by experts, namely accountants, knowledge about bookkeeping plays an important role for entrepreneurs and becomes the basic capital of corporate management in terms of finance.

\section{Simple Bookkeeping Stages}

In the financial management of a business unit, a step in the bookkeeping process is needed, namely:

1. To separate business finance with personal money.

2. Determine the amount of financial percentage that will be used for the needs business.

3. Plan the use of money, as much as possible reduce the risk of business debt.

4. Make financial accounting neatly

5. Play cash flow faster: Don't just focus on profit. Financial management includes how you manage debt, accounts receivable and merchandise inventory.

6. Always oversee the position of assets, debt, and capital.

7. Always control cash flow

8. Calculate Profit and Loss correctly. The most critical part of calculating profits is calculating costs. Most of the costs can be known because it involves the payment of cash. Some of the others are not cash, such as depreciation and amortization. Some of them have not happened yet but need to be reserved to be issued in the future, such as taxes and loan interest.

9. Set aside profits for business development: set aside some of the profits for business development.

\section{Vegetable Vendors}

According to the Regional Regulation of Bogor City number 13 of 2005 concerning the arrangement of street vendors. Street vendors are sellers of goods or services that individually and or business groups in economic activities classified as small-scale businesses that use public facilities and are temporary or not 
settled by using movable or immovable equipment and/or using trading facilities that are easy to move and install and install.

According to Ramli in Zuhriski [2], street vendors are interpreted as small-scale community businesses engaged in the trading of relatively small, limited and non-permanent business environments. In this sense, street vendors are often clinging to the characteristics of small money circulation, places of business that are not fixed, capital is limited, market segments in the lower middle-class society and the business scope is not too broad.

The main characters of vegetable traders are:

1. Make sure that the merchandise is sold out that day. This is because the merchandise is not durable or the amount is small, so it is expected that there will be a capital turnover. As a result, the vegetable trader will try to be as close as possible to the prospective buyers.

2. Work every day as long as conditions permit.

3. The method of presentation and packaging of goods is very simple. Packaging tends to leave waste and reduce product quality both physically and aesthetically.

4. Usually the types of vegetables sold change according to the vegetable growing season.

The price offered fluctuates because it adapts to the conditions of the commodity, merchandise and trading time and scarcity of goods and bargaining power (Murtadlo,[7]).

\section{RESEARCH METHODS}

This type of research is descriptive development with descriptive survey research methods and qualitative research techniques.

Data collection techniques: primary data is data obtained directly from the answers to questionnaires from respondents who were sent directly to vegetable vendors in the Bogor region by involving students in the process of disseminating, interviewing and gathering. While secondary data is obtained from variously related literature, books, and journals.

Taking respondents who are the sample in this study was conducted at the vegetable vendors. Sampling using the stratified sampling method is the method of taking respondents by grouping by region. The number of samples taken was 34 people from 92 populations spread across the Bogor region.

\section{Data Processing / Analysis Method}

Data processing is done by using Microsoft Excel 2010 computer software. Data analysis will be carried out through frequency tabulation (the process of calculating the frequency that is counted on the respondent's answers in the questionnaire into each category).

\section{RESULTS AND DISCUSSION}

\section{General Description of the Research Area}

East Bogor is a sub-district in Bogor City, West Java Province, Indonesia. In this sub-district, the Katulampa Water Gate is located, which is a popular sluice gate especially when the middle rainy season hits Jakarta. This subdistrict is bordered by the North Bogor sub-district in the north, Central Bogor in the west, South Bogor in the south, and Bogor Regency in the east.

Based on government regulation Number 2 of 1995 and Inmendagri No. 30 of 1995 dated August 24, 1995, concerning Amendments to Regional Territories of the Regional Government of Tk. II Bogor and Regional District Tk. II Bogor, East Bogor District area with an area of 1,015 Ha, consisting of 6 (six) villages $318 \mathrm{RT}$ and $59 \mathrm{RW}$.

The villages referred to are:

1. Baranangsiang Village Area $235 \mathrm{Ha}$

2. Sukasari Village Area $48 \mathrm{Ha}$

3. Katulampa Village Area $491 \mathrm{Ha}$

4. Tajur Village Area of $45 \mathrm{Ha}$

5. Sindangsari Village Area of $90 \mathrm{Ha}$

6.Sindangrasa Village Area of $106 \mathrm{Ha}$

The northern boundary borders on Kec. North Bogor, on the east bordering Sukaraja District, Kab. Bogor, on the west, bordering Kec. South Bogor and Kec. Central Bogor and the south bordering Kec. Ciawi Kab. Bogor.

The area and population according to the subdistrict in the city of Bogor, the author found in the Bogor City Statistic Bureau from 2011 to 2014 are presented in table 2 .

Table 2. Area and Population by District in Bogor (BPS Bogor 2004 [1])

\begin{tabular}{|c|c|c|c|c|c|}
\hline \multirow{2}{*}{ Kecamatan/Subdistrict } & \multicolumn{2}{|c|}{ Luas/Area } & \multicolumn{2}{|c|}{$\begin{array}{l}\text { Penduduk (orang)/ Population } \\
\text { (Person) }\end{array}$} & \multirow{2}{*}{$\begin{array}{l}\text { Kepadatan Penduduk / } \\
\text { Population Density }\end{array}$} \\
\hline & $\mathrm{Km}^{2}$ & $\%$ & JumlahTotal & $\%$ & \\
\hline 1. Bogor Selatan & 30.81 & 26.00 & 194179,00 & 19.05 & 6302,00 \\
\hline 2. Bogor Timur & 10.15 & 8.57 & 101984,00 & 9.99 & 10048,00 \\
\hline 3. Bogor Utara & 17.72 & 14.95 & 186098,00 & 17.96 & 10502,00 \\
\hline 4. Bogor Tengah & 8.13 & 6.86 & 104120,00 & 10.56 & 12807,00 \\
\hline 5. Bogor Barat & 32.85 & 27.72 & 228860,00 & 22.21 & 6967,00 \\
\hline 6. Tanah Sareal & 18.84 & 15.90 & 215479,00 & 20.23 & 11437,00 \\
\hline 2014 & 118.50 & 100.00 & 1030720 & 100.00 & 8698 \\
\hline 2013 & 118.50 & 100.00 & 1013019 & 100.00 & 8549 \\
\hline 2012 & 118.50 & 100.00 & 1004831 & 100.00 & 8480 \\
\hline $2011^{1}$ & 118.50 & 100.00 & 987315 & 100.00 & 8332 \\
\hline
\end{tabular}

The proportion of the population that can be categorized by male and female sex and at age can be seen in the form of a pyramid chart in Figure 1. 


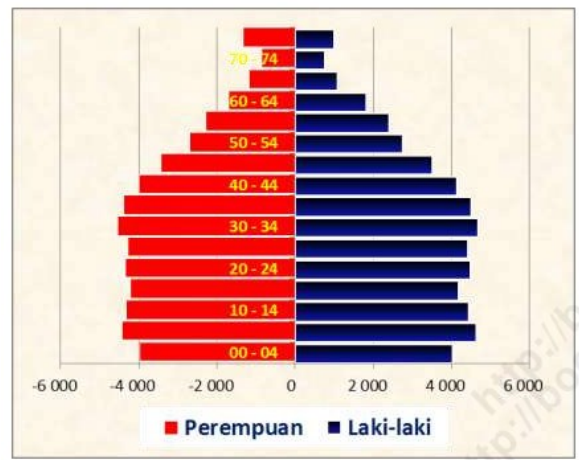

Source: Bogor Central Bureau of Statistics

Figure 1. Pyramid of Population in East Bogor District in 2016

\section{Desription of Responndent}

The respondent's description in this study is the description/condition or characteristics of the respondents who were sampled namely the vegetable sellers in the East Bogor District. The sample description includes age, education, experience, capital, sales, and purchase activities and their ability to manage their finances.

The number and percentage of respondents based on age groups can be seen in figure 2 below:

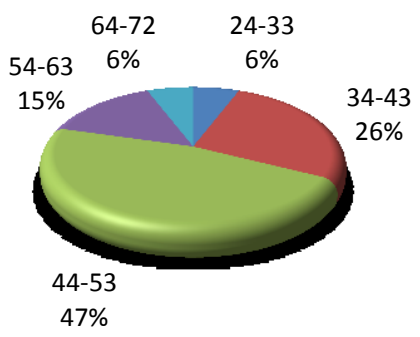

Figure 2 Graph of characteristics of mobile vegetable traders based on age In the East Bogor District 2018 (source: primary data processed by the author)

Based on Figure 2, it can be seen that from the total number of respondents totaling 34 people, as many as 2 people or $6 \%$ aged 24-33 years, 9 people or $26 \%$ aged $34-43$ years, 16 people or $47 \%$ aged $44-53$ years , 5 people or $15 \%$ aged $54-63$ years and 2 or $6 \%$ aged 64-72 years.

The number and percentage of respondents based on education level can be seen in figure 3 . Based on figure 3 , it can be seen that the education level of respondents is formal education taken by each sample by obtaining a diploma. Sample characteristics based on education can be seen that as many as 4 people or $12 \%$ have high school education, then as many as 8 people or $24 \%$ have junior high school education, 14 people or $41 \%$ have elementary school education, and as many as 8 people or $24 \%$ have no education.

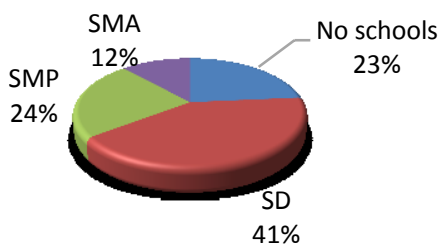

Figure 3. Graph of characteristicsof mobile vegetable traders based on education In the East Bogor District 2018 (source: primary data processed by the author)

The number and percentage of respondents based on the length of time they run a business can be seen in Figure 4 below:

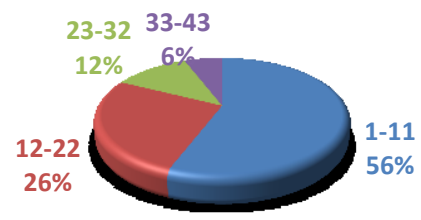

Figure 4. Graph of characteristics of mobile vegetable traders based on experience In the East Bogor District 2018 (source: primary data processed by the author)

The experience of trading vegetables around is the length of time the respondents run their businesses in vegetable trading by traveling to areas that respondents do base on the routes they take in their daily lives. Based on table 5 and graph 4, it can be seen that the number of respondents is 19 people or $56 \%$ have experience for 1-11 years, as many as 9 people or $26 \%$ have experience of 12-22 years, as many as 4 people or $12 \%$ have experienced $23-32$ year and as many as 2 or $6 \%$ have experience of 33-43 years.

The number and percentage of respondents based on vegetable trading capital can be seen in the following picture:

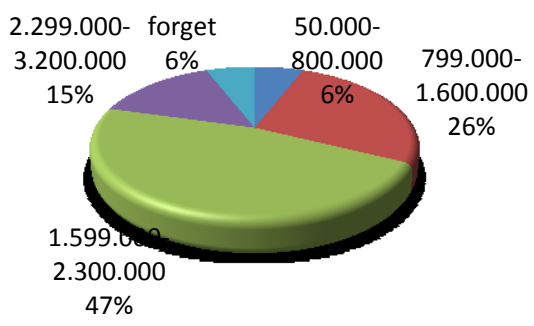

Figure 5 Graph of characteristics of mobile vegetable traders based on capital In the East Bogor District 2018 (source: primary data processed by the author)

Business capital in trading vegetables around is the capital used to buy vegetables and equipment which the respondent runs his business every day. 
Based on table 6 and figure 5, it can be seen that the number of respondents is 2 people or $6 \%$ have capital ranging from Rp50,000-Rp800,000, 9 people or $26 \%$ have capital ranging from Rp799,000-Rp1,600,000, 16 people or $47 \%$ have capital ranging from Rp1,599,000Rp. $2,300,000,5$ people or $15 \%$ have capital ranging from Rp.2,999,000,000-Rp.3,200,000 and as many as 2 people or $6 \%$ do not remember the amount of initial capital.

Based on the source of capital, as many as 26 people or $76 \%$ claimed that the source of capital was personal, while as many as 8 people or $24 \%$ said that they obtained it from the loan came from relatives or neighbors, as shown in figure 6 below:

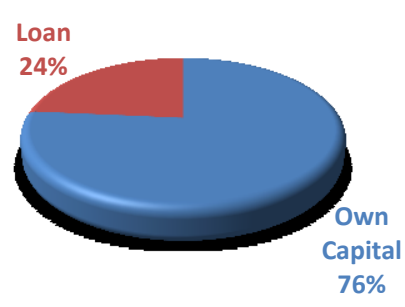

Figure 6. Graph of characteristics of mobile vegetable traders based on the source of capital In the East Bogor District 2018 (source: primary data processed by the author)

In carrying out their daily business, the vegetable sellers in the East Bogor District, 12 people or $35 \%$ start their business from $05.00 \mathrm{WIB}$, as many as 12 people or $35 \%$ starting from $06.00 \mathrm{WIB}, 7$ people or as much as $21 \%$ start their business at 07.00 while 2 people start at 08.00 and as many as 1 people or $3 \%$ the average starts from WIB as shown in figure 7.

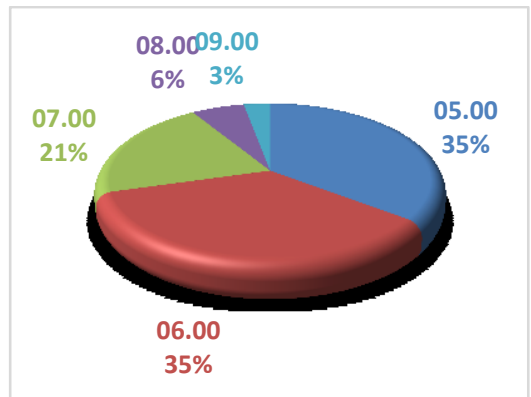

Figure 7. Chart of Characteristics of Roving Vegetable Traders based on Time to Start Trading In the East Bogor District 2018 (source: primary data processed by the author)

The length of the vegetable vendors in East Bogor Subdistrict in traveling around selling merchandise every day is varied, as many as 5 people or $15 \%$ on average finished at $09-11 \mathrm{WIB}, 19$ people or $56 \%$ on average finished at $12-14$ WIB and as many as 10 people or $29 \%$ finished at $15-17$ WIB as shown in figure 8 .

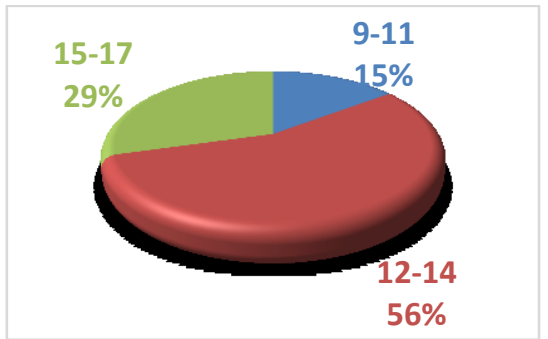

Figure 8. Graph of characteristics of mobile vegetable traders based on time of completion of the trading In the East Bogor District 2018 (source: primary data processed by the author)

Profits or profits generated by the vegetable sellers in the East Bogor District vary, as many as 23 people or $68 \%$ get a profit of around Rp. Rp. 270,000, 7 people or $21 \%$ get a profit ranging from Rp. 271,000 to $\mathrm{Rp}$. 465,000 people or $9 \%$ net profits ranging from Rp. 466,000 to Rp1,197,000 and 1 person or $3 \%$ gets a profit ranging from Rp1,198,000 to Rp. 3,700,000 as shown in figure 9.

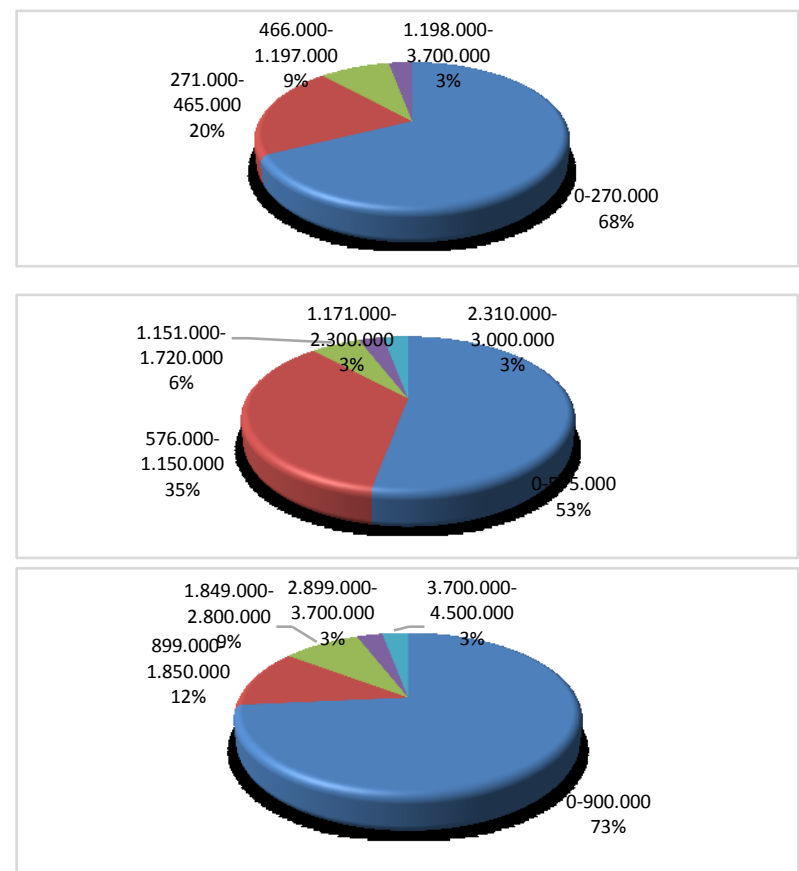

Figure 9. Chart of Characteristics of Roving Vegetable Traders based on Sales, Cost of Sales and Profit Generated In the East Bogor District 2018 (source: primary data processed by the author)

In fact, the profit calculation that the mobile vegetable traders do is wrong. it can be concluded that they still cannot afford to analyze and calculate profits from the sale of merchandise. It is evident that 22 people or $65 \%$ have not been able to calculate their own profits and 12 people or $35 \%$ have been able to calculate it. As seen in the following figure 10: 


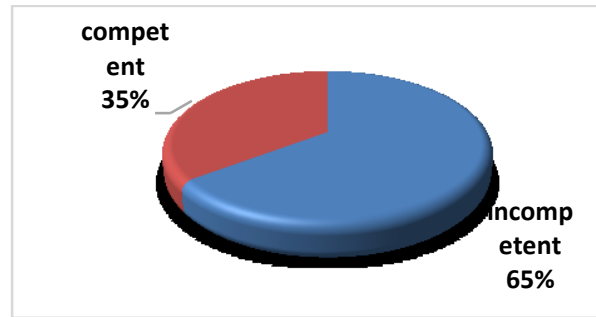

Figure10 Chart of Characteristics of Roving Vegetable Traders based on Ability to Calculate Profit In the East Bogor District 2018 (source: primary data processed by the author)

Various ways done by the vegetable sellers in determining the price of vegetables that are damaged or unsold, such as selling below the normal price, are given to customers in the form of a bonus if the customer buys an amount that exceeds the general customer, free of charge to customers who wanted, consumed by his family and others who threw it away.

The sales system carried out various ways they do, there are those who via SMS, cell phone or order H-1 from their customers, via SMS, there is also a cell phone that orders one day before but there are also those who never receive orders.

\section{Buying Activity}

The traders must prepare the merchandise as best they can. Various times that are carried out by the traders in preparing it by buying it to the selected traditional market. As many as 3 people or $9 \%$ chose to leave between 00-01 WIB to buy their merchandise because in order to have more time to prepare and fresh air, 15 people or $44 \%$ chose to leave between $02-03$ WIB, as many as 15 people or $44 \%$ choose to go between 04-05 WIB on the grounds that they want to do morning prayers first and between 06-07 WIB one person or $3 \%$ purchase their merchandise on the market. The data is shown in the following figure 11.

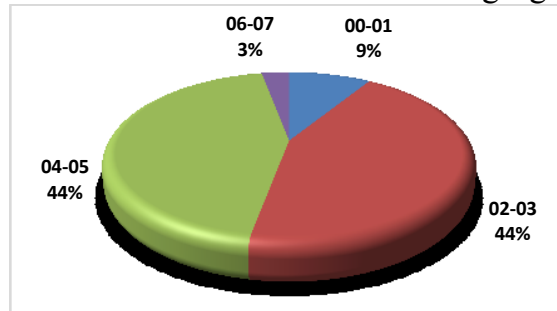

Figure 11 Chart of Characteristics of Roving Vegetable Traders based on Time to Start Buying Goods In the East Bogor District 2018 (source: primary data processed by the author)

\section{Financial Management Activities}

The ability of mobile vegetable traders in the East Bogor District region to manage their finances is very diverse. A good and professional entrepreneur should be able to separate his finances between managing his business and personal life. However, there are still many mobile vegetable traders who do not understand that. As many as 6 people or $18 \%$ do not separate their finances between personal and business and as many as 28 people or $82 \%$ who separate them. This reflects that in general traders understand to control their finances. This information can be seen in the following figure 12 .

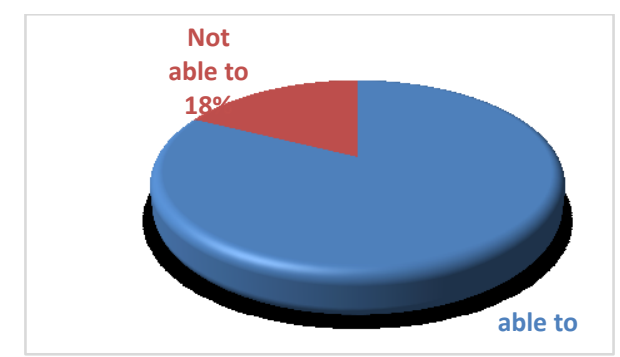

Figure12 Chart of Characteristics of Roving Vegetable Traders based on Ability to Separate Finances Between Personal and Business In the East Bogor District 2018 (source: primary data processed by the author)

The economic situation of the people of the East Bogor Subdistrict, especially vegetable sellers, is still relatively capable in terms of board needs even though it is still very far from family livelihood, seen in table 13 and figure 12 as many as 12 people or $35 \%$ have not lived or where he came from but they rented a house for their stay. As many as 22 people or $65 \%$ have homes in both the area where they sell and in their hometowns. Also in terms of vehicle ownership, as many as 22 people or $65 \%$ have motorbikes either by credit or cash and 12 or $35 \%$ do not have a vehicle, as shown in figure 13 below.

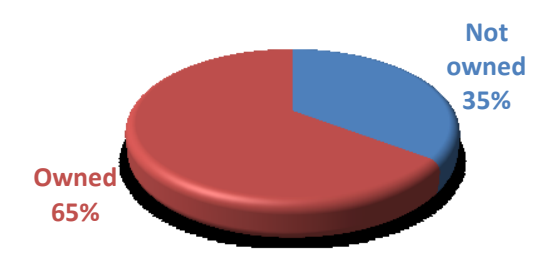

Figure13 Chart of Characteristics of Roving Vegetable Traders based on Housing Ownership In the East Bogor District 2018 (source: primary data processed by the author)

In fulfilling their daily needs, the traders not only relied on their efforts to trade, but there were also those who were carried out by way of debt, some were neighbors, to stalls that were adjacent to their homes to mobile banks as moneylenders and some don't. The information in figure 15 explains that as many as 17 people or $50 \%$ are both in debt and not. 


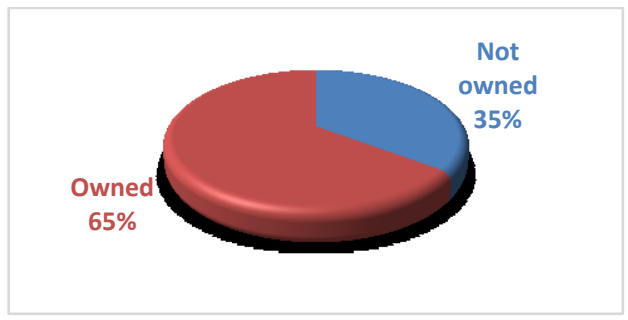

Figure14 Chart of Characteristics of Roving Vegetable Traders based on Motorbike Ownership In the East Bogor District 2018 (source: primary data processed by the author)

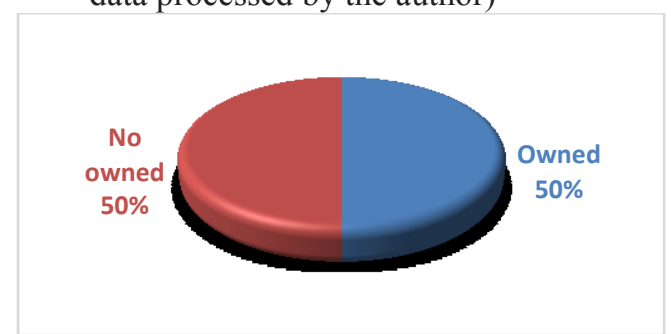

Figure15 Chart of Characteristics of Roving Vegetable Traders based on Debt Ownership In the East Bogor District 2018 (source: primary data processed by the author)

When respondents are interviewed and based on the results of the questionnaire it can be seen that as many as 13 people or $38 \%$ feel the need to record the entry and exit of selling money so that the cash flow from their operations can be seen but 21 people or $62 \%$ do not feel the need to record money in and out of ignorance they will do this which makes them reluctant to continue to develop and change to see their educational background as well which results in no sense of wanting to make changes in their lives, as presented in figure 16.

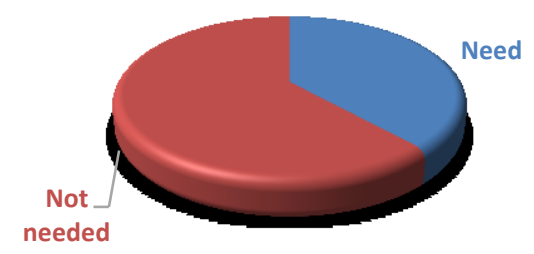

Figure 16 Chart of Characteristics of Roving Vegetable Traders based on The Desire to Make Notes To Enter And Exit Money In the East Bogor District 2018 (source: primary data processed by the author)

When traders strive to sell their merchandise, various methods are carried out by them, namely by selling in cash or on credit. Most buyers who are customers are given leeway on the payment system. In figure 19 , there are 23 people or $68 \%$ of the traders who have receivables to their customers and as many as 11 people or $32 \%$ do not apply credit sales, which means they do not have receivables.

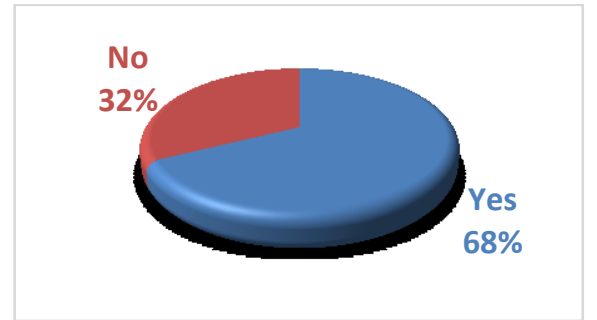

Figure17 Chart of Characteristics of Roving Vegetable Traders based on Ownership of Receivables In the East Bogor District 2018 (source: primary data processed by the author)

Every human being is measured by the level of satisfaction in carrying out life and endeavors to make daily living and certainly will never feel satisfied. But the author can retrieve information from respondents' data that as many as 23 people or $67 \%$ feel satisfied and grateful in their current situation, as many as 6 people or $18 \%$ feel quite satisfied even though many needs have not been fulfilled, but still grateful and as many as 5 people or $15 \%$ feel dissatisfied with their reasons because of the many needs and items they want but cannot afford to buy. This information is presented in figure 18.

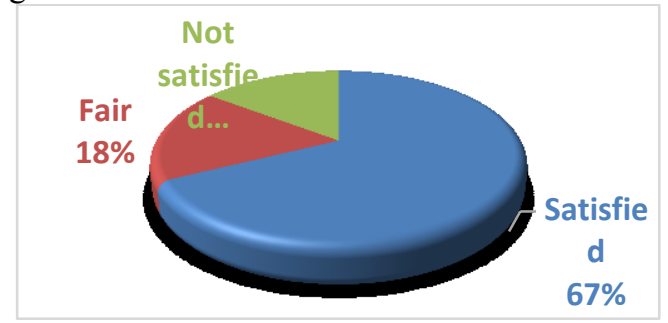

Figure18 Chart of Characteristics of Roving Vegetable Traders based on Satisfaction with the Current Situation In the East Bogor District 2018 (source: primary data processed by the author)

Efforts made by vegetable vendors in the area of East Bogor Subdistrict in fulfilling their daily needs sometimes yield results that can fulfill their daily needs or vice versa. Seen as many as 22 people or $65 \%$ of traders felt that they were enough to sell vegetables around in fulfilling their daily needs, as many as 12 people or $35 \%$ felt they were not enough or not enough. This information is obtained from the data in figure 19.

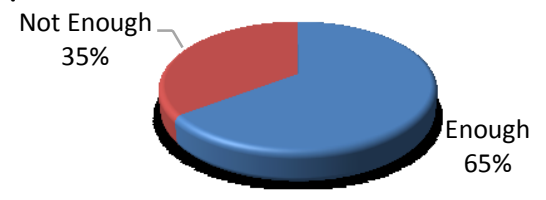

Figure19 Chart of Characteristics of Roving Vegetable Traders based on Adequacy of Sales Results in Meeting Life Needs In the East Bogor District 2018 (source: primary data processed by the author) 
Respondents thought that as many as 6 people or $18 \%$ wanted to switch professions from mobile vegetable traders because the results were less satisfactory and even then if there were other business opportunities they could do. A total of 28 people or $82 \%$ felt they did not want to change professions from vegetable traders because they were comfortable, felt that they were quite old, long time to sell and spare a large number of customers. This is presented in figure 20.

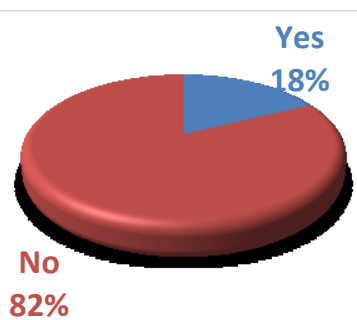

Figure20 Chart of Characteristics of Roving Vegetable Traders based on Desire to Switch Profession In the East Bogor District 2018 (source: primary data processed by the author)

The researcher offered a solution contained in a questionnaire to vegetable traders in the East Bogor District for financial management so that they could help organize their finances. As many people or\% want to learn to manage their finances better with the average reason that they know their income and expenses in running their business, want to get more profits, order lives and can save for their families. But as many people or $\%$ feel they don't want to learn to manage finances better because this is considered complicated and difficult to understand and also they feel satisfied with the current situation. This information is presented in figure 21 .

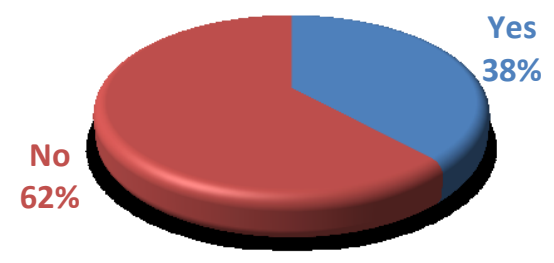

Figure21 Chart of Characteristics of Roving Vegetable Traders based on The Desire to Learn to Manage Business Finances In the East Bogor District 2018 (source: primary data processed by the author)

\section{CONCLUSION}

Based on the objectives of this study, it can be concluded that there are still vegetable vendors who do not have simple bookkeeping skills for the East Bogor Region. This is evidence that there are still many who do not separate the financial management of their business with their personal lives. There are also some people who feel that they do not need to make notes on the entry and exit of the proceeds of selling because they think it is too complicated and time-consuming, even though they themselves have difficulty in knowing the actual benefits of selling as much. There are also traders who borrow their working capital from moneylenders due to their lack of understanding of the impact of what they do.

\section{Suggestion}

Based on the results of this analysis, the researcher proposes several suggestions as input and considerations that are expected to improve the ability of simple bookkeeping knowledge and skills later, including the following:

1. For mobile vegetable traders who are the subjects in this study: they have to know and improve their abilities in simple financial management and bookkeeping. Be grateful for all the blessings given by the Almighty in his life.

2. For further researchers so:

a. It is not only analyzing exploratively descriptively surveys but more about the explanatory survey, which is analyzing what factors make indicators of the success of vegetable traders in managing their finances.

b. In order to be widely used, the next research subject should be extended not only to the East Bogor Subdistrict, but it can also be done in all sub-districts in Bogor City, and in other wider regions.

c. Local governments are expected to facilitate education and training for small businesses so that their lives will be further enhanced which will have an impact on broad economic prosperity.

\section{REFERENCES}

[1] https://bogorkota.bps.go.id/publication/2017/08/ 07/ 515a 06087f4e7 5330db2a889/ produkdomestik- regional -bruto- kota- bogor-menurutlapangan-usaha-2012-2016.html. 2016

[2] Zuhriski, Hemnur. 2008. Analisis Pendapatan Pedagang Sayur Keliling di Kelurahan Tegallega Kota Bogor.

[3] https://en.wikipedia.org/wiki/Critical_thinking. 2016.

[4] Goleman, Daniel. 2000. Working With Emotional Intelligence. Jakarta: PT

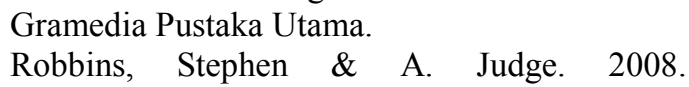
Perilaku Organisasi. (Organizational Behaviour). Edisi 12 jilid 1\&2. Jakarta: Penerbit Salemba Empat. 
[6] Darsono dan Ashari. 2005. Pedoman Praktis Memahami Laporan Keuangan. Yogyakarta: ANDI.

[7] Murtadlo, Nurasiah Al. 2007. Pengaruh Modal dan Lokasi terhadap Pendapatan Pedagang Kaki Lima Pakaian Jadi di Pasar Anyar Kota Bogor. Skripsi. Fakultas Ekonomi dan Masyarakat. Institut Pertanian Bogor. 